\title{
THE LOGIC PROBABILITY ON HADITH (COUNTING GENDER OCCUPANTS OF HEAVEN AND HELL)
}

\author{
Ruhama Wazna and Hamim Ilyas \\ Universitas Islam Negeri Sunan Kalijaga Yogyakarta, Indonesia \\ ruhama_w@yahoo.co.id \\ Article history: \\ Submitted: 26-06-2019 | Revised: 20-09-2019 | Accepted: 06-11-2019
}

\begin{abstract}
This study aims to explore probability as one of the new methods of understanding the hadith about the majority of women who inhabit hell by integrating the ratio of male and female hadith at the end of time as the counting scale. The use of the thematic-multidimensionality method, this study construed and elaborated the related hadith (al-jam'u bain al-adillah). The results of the study revealed that the more women than men in the world, affecting the majority of women as residents of heaven and hell, and vice versa, affecting the minority of men as residents of heaven and hell. It proves the misogyny assumed in the hadith was not essential. Thus, it is not appropriate if this hadith used as a tool to discredit women have a bad character so that they become the most occupants of hell than men, or conversely reject the hadith that is authentic only because of reasons contrary to reason.
\end{abstract}

Keywords: Misogyny Hadith, Gender, Women and Hell

\begin{abstract}
Abstrak
Artikel ini bertujuan untuk memproyeksikan hitungan peluang (probabiltas) sebagai salah satu metode pemahaman baru terhadap hadis tentang perempuan mayoritas penghuni neraka dengan menghubungkan hadis rasio laki-laki dan perempuan di akhir zaman sebagai skala hitungannya. Metode tematik-multidimensionality digunakan untuk merangkum dan mengkonsiliasi hadis-hadis terkait (al-jam'u bain al-adillah). Hasil penelitian ini menunjukkan bahwa jumlah perempuan yang lebih banyak dari pada laki-laki di dunia, berdampak pada mayoritasnya perempuan sebagai penghuni surga maupun neraka, demikian juga sebaliknya, laki-laki minoritas sebagai penghuni surga maupun neraka. Hal ini sekaligus membuktikan bahwa misogini yang diasumsikan pada hadis bukanlah bersifat haqiqi. Dengan demikian, maka tidaklah tepat jika hadis ini digunakan sebagai alat untuk mendiskreditkan perempuan dengan alasan perempuan memiliki watak yang buruk sehingga menjadi penghuni neraka terbanyak dibandingkan laki-laki, atau sebaliknya menolak hadis yang shahih isnadnya hanya karena alasan bertentangan dengan akal.
\end{abstract}

Kata Kunci: Hadis Misogini, Gender, Perempuan dan Neraka 


\section{Introduction}

Humans are not able to particular the future or something that hasn't happened yet, especially in the realm of eschatology. ${ }^{1}$ But at least humans can predict the likelihood of what will happen and measure how likely it will be. This action is based on the logic of probability, although in the end, it cannot ensure. However, it gives limit the likelihood of an event occurring. This logic can be applied in the hadith, especially to the hadith displayed figures and quantity, such as hadith about the number of women in heaven and hell. The hadith exhibited a specific number in the form of a general description such as the

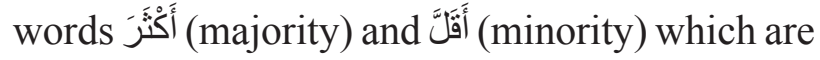
narrated from various lines of sanad and matan editors and found in several canonical hadith books both in the saheeh, sunan and musnad. These included problematic hadith; the scholars differed in interpreting, some accept the hadith with a textual understanding approach, and some are contextual, even reject the authenticity of the traditions. $^{2}$

${ }^{1}$ Eschatology is Greek which is currently used in theological studies and religious studies (since the mid-19th century) encompassing four areas of study namely; death, decision, heaven and hell. Eschatology can be divided into 4 types, namely: Individual Eschatology, Universal Eschatology, Topographic Eschatology and Historical Eschatology. The hadith in this study can be categorized in Topographic Eschatology because it includes explaining the detailed situation in heaven and hell (in this study is the condition of the number of women living in hell). For more details see: Sebastian Gunther and Todd Lawson, Road to Paradise: Eschatology and Concepts of The Hereafter In Islam (Boston: Brill, 2017), 5, 13-15.

${ }^{2}$ As with scientific studies in general, the methodology in a study of the understanding of the "misogyny" hadith of the majority of women who inhabit hell is also a major determinant in producing conclusions. Textual understanding of this hadith can degrade women, while contextual understanding also has a variety of conclusions which among other things cannot be guaranteed to be free from gender bias elements, such as Rahmin Talib Husain comprehensively understand the meaning of اكثر اهلهاالنسا according to him it is not a woman in the form of gender but it is understood with the "many problems" that demand the heavy and heavy responsibilities that frame women. If so, what about men who also have many problems that demand big and heavy responsibilities that are not less compared to women? So interpretations like this are considered to be precisely the problem of new gender biases. See: Rahmin Talib Husain, "Women in the Shackles of Hell (Misogynist Hadith Criticism)," UNIVERSUM Journal: Journal of Islam and Culture 11, no.2. (2017): 87.
The problem was not to focus on the majority or minority of women in hell or heaven, but the more obvious impact of misconception was that the adverse effects of internal and external of women. The internal was the emergence of an inferiority complex in women and feeling intimidated by the 'threat' of being a dweller of hell. The external was the emergence of stereotypes of men to women as creatures that are closer to negative attitudes so that they were more likely to become residents of hell. If the stereotype occurred, it would be gender injustice; women became victims of interpretations of religious texts, gender-biased regulations especially in the case of the household. A husband would be easily made these traditions as a tool to threaten his wife to submit and obey despite in bad behavior. On the other hand, rejecting the hadith about the majority of women who live in hell whose isnad has been agreed by jumhur Sunni scholars, but the reason was contrary to common sense. Yet, what happened was not opposed; it needs to be reviewed; one's understanding of the hadith had not reached the true nature or loss of context on understanding the hadith partially. ${ }^{3}$ If it happens undermine other shahih hadith that are contrary to reason.

Furthermore, a new understanding method needs to interpret women on the eschatological domain of the quantity of the inhabitants of heaven and hell. So that the collection of Islamic texts, especially Hadith, is not easily broken down and avoiding Islam from the impression of a misogynistic religion by giving attention to the principles of the method of understanding Hadith. $^{4}$

\footnotetext{
${ }^{3}$ See: Abdul Mustaqim, Ilmu Ma'anil Hadis; Paradigma Interkoneksi Berbagai Metode dan Pendekatan dalam Memahami Hadis Nabi (Yogyakarta: Idea Press, 2016), 34.

${ }^{4}$ Some principles of the method of understanding the hadith are not in a hurry to reject a hadith just because it is considered contrary to reason, understanding the hadith with a thematic (maudhu'i), doing a textual analysis of language; distinguish legal-formal hadith with aspects that are morally ideal; distinguish between traditions that are local-cultural, temporal and universal; consider position; scrutinizing the faith of sanad
} 
Based on the background and significance, it is crucial to put forward the related hadith and investigated various hadith or syarah from scholars as part of the discourse on the likelihood of events, as well as how to use probability methods to identify how much chance the opinions would occur, it is an effort to respect an ideal understanding of the number of women in eschatology, especially heaven and hell.

\section{The Logic of Probability in The Study of Hadith}

Probability $^{5}$ is opportunity. Opportunity is a way to express a chance for an event to occur. Qualitatively, it can be shown in the form of adjectives to indicate the possibility of a situation such as good, weak, strong poor and few. Quantitatively, opportunities are expressed as numerical values, both infractions and decimals between 0 and 1 . Opportunity equal to 0 means that an event cannot occur, while a chancesimilar to 1 means that the event must occur. ${ }^{6}$ The probability for event $\mathrm{E}$ is $\mathrm{P}(\mathrm{E})$, and the $\mathrm{P}(\mathrm{E})$ value limit is $0 \leq \mathrm{P}(\mathrm{E}) \leq 1$, meaning: if $\mathrm{P}(\mathrm{E})=0$ means that event $\mathrm{E}$ is definitely not happening, whereas if $\mathrm{P}(\mathrm{E}))=1$ means event $\mathrm{E}$ is bound to occur.

and matan; ensure that the text of the hadith does not conflict with other texts that are stronger; and interconnect with modern scientific theories. See: Yusuf Qaradhawi, How to Understand the Prophet's Hadith. Translated by Muhammad al-Baqir (Bandung: Charisma, 1993), see also: Sa'duddin al-Uthmani, alManhaj al-Wasath fi al-Ta'amul maa al-Sunnah al-Nabawiyyah (Egypt: Dar Kalimah, 2012), both in Abdul Mustaqim, Science Ma'anil Hadith ..., 33-36.

${ }^{5}$ If examined in various sources of statistical science, the probability is referred to by several terms; probability method, probability theory, probability logic, probability calculation and probability approach. But as if everything has the same purpose, because it has the same scope of discussion. In this paper, the author also uses the word probability repeatedly as for what is meant can mean methods, theories, logic, calculations and approaches in accordance with the purpose of the conversation in a sentence. The probability/ probability theory that is part of Mathematics is a theory inspired by the problem of gambling. The main character is Girolamo Cardano (1501-1576) Italian scientist and true gambler. Thanks to his efforts, he succeeded in compiling a book entitled Book on Dice Games in 1965. See: Moh. Farhan Qudratullah et al, Statistics Method (Yogyakarta: Academic Field of UIN Sunan Kalijaga, 2008), 81-82.

${ }^{6}$ See: B.S. Soedibjo, "Statistika," in Imam Gunawan, Pengantar Statistika Inferensial (Jakarta: Raja Grafindo Persada, 2016), 23-23.
What often happensusually is the value of $\mathrm{P}(\mathrm{E})$ is between 0 and $1 .^{7}$ The possibility of something happening that has a level/degree. Probability is expressed as a decimal number or fraction, the closer the probability value to the value 0 , the less likely an event will occur, conversely the closer the probability value to the value 1 , the higher the chance an event will occur. ${ }^{8}$ The limits value must be met, and the probability distribution function must not be negative. ${ }^{9}$ Probability can be used not only for the scientific sciences but also for the social sciences. About the hadiths, the scholars have always revealed the existence of certainty in the hadith, even though the phrase is named differently - not using the term probability.

The result of literature review exhibited that Halis Aydemir ${ }^{10}$ has begun to use probability as one of the methods to find out the numerical value of narrators at various levels in isnad, to be accurately identified whether or not a transmission pathway, the use of the probability method as a mathematical part in each study looks in-depth, so it is not surprising if in his writings found various a mathematical formula of probability when it expresses the narrator's quantity at multiple conditions and levels of sanad. ${ }^{11}$ Aydemir's consistency in studying the transmission or narration of the hadith with the probability method has made a real contribution in enriching the treasure of the hadith methodology,

\footnotetext{
${ }^{7}$ Ibid., 30.

${ }^{8}$ See: Meilia Nur Indah Susanti, Statistika Deskriptif dan Induktif (Yogyakarta: Graha Ilmu, 2010), 154.

${ }^{9}$ J.Supranto, Statistik Teori dan Aplikasi, Vol. II (Jakarta: Erlangga, 2001), 5.

${ }^{10}$ Halis Aydemir (45 years), is a Turkish national. He earned his bachelor's degree at Istanbul Technical University (ITU) in the Department of Electrical and Electronics Engineering (1995) and completed his Master's education at Uludağ University, Institute of Social Sciences on Hadith (1998), at the university and similar fields he completed his Ph.D. (2004) and successfully bears the title of Professor (2008) with the study of 'Nafi' Maula ibn Umar in The Light of the Probability of Narrations Theory. At present, he focuses on the field of probability based on narrative system analysis, orientalism and investigation. See: https://openlibrary. org/authors/OL6884914A/Assoc._Prof._Dr._Halis_Aydemir, accessed on 25 September 2019.

${ }^{11}$ See: Halis Aydemir, Probability of Narration; a Theoretical Approach (USA: LuLu Press, 2007).
} 
but it is precisely what distinguishes this paper, the probability was no longer directed at the transmission side of the hadith, but instead led to understand the meaning of matan (ma'ani alhadith) especially the hadith about the gender of the inhabitants of heaven and hell.

Mun'im Sirry in his book Islamic Intellectual Tradition directly linked probability with hadiths; this is not as a method of understanding certain traditions but as a theory that produces several concluding statements. i.e., the mutithah ma'nawi hadith may not reach the same degree as the mutikir lafdzi; the level of authenticity of ahad was very doubtful; Mun'im Sirry in his book Islamic Intellectual Tradition directly links probability with hadiths; this is not as a method of understanding certain traditions but as a theory that produces several concluding statements. i.e. the mutithah ma'nawi hadith may not reach the same degree as the mutikir lafdzi; the level of authenticity of ahad is very doubtful; the higher the level of probability contained by authentic hadiths, the closer a fakih is to the highest truth he is about to achieve; and in the view of the hadith expert the more adherent to the hadith the more a person is considered pious, even though the tradition has a low probability. ${ }^{12}$ Sirry did not explain in detail the use of probability theory, only limited to the number 0.5 for half the possibility and 1.0 for the highest degree of certainty. According to him the hadith of ahad or muthatin 'failed to pass the probability test with a certainty level of 1.0 and if it was still measured with probability the range was between 0.51 and not reaching 1.0.

However, Sirry has explained the polemic of the assumption of 'certainty' or 'uncertainty' in the hadith along with the terms used; Abu "Amr Ibn Shalah called it "al dzann qad yukhti" (estimates could be wrong), the expert on the jurisprudence of Imam Sarakhsi called it " $[a l$ ahad] fihi ihtimal wa syubhah" (in hadith ahad

\footnotetext{
${ }^{12}$ See: Mun'im Sirry, Tradisi Intelektual Muslim; Rekonfigurasi Sumber Otoritas Agama (Malang: Madani, 2015),125-127.
}

there are possibilities and subhats), imam anNawawi (w.676 H. /1277 AD) who tend to be careful in practicing sahih hadith unless they were classified as muthat, said: "wa idza qila sahih, fa hadza ma'nahu la annahu maqthu'un bihi (if a hadith was said to be shaih, this does not mean giving certainty). Besides, Sirajuddin al-Bulqani (w.805 H. / 1402 AD), made a list of hadith scholars supported by Ibn Salalah's view that the authentic category of hadith agreed by Bukhari and Muslims provided certainty (yaqini nadzari), although they admitted the hadith have probabilities, but the factor of the existence of ijma' made at the level of certainty. ${ }^{13}$

\section{Hadiths About The Quantity of Women in Hell and Heaven}

The issue of women as the most inhabitants of hell attracts the attention of scholars, according to Anne Sofie Roald, the hadith about women in hell is the most commonly quoted hadith in the Arab and European world when it concerns the position of women in Islam, and heated discussion ensues, on anti-Islamic hadith sites taken as final proof that Islam is a misogyny, while most Islamic sites debate it. ${ }^{14}$ Even though the hadith about women in hell is more desirable, but the hadith about the number of women in heaven and the hadiths that have the same theme are shared in this study (wihdah al-mawdu'iyyah fi al-hadith). ${ }^{15}$

\footnotetext{
${ }^{13} \mathrm{See}$ Abu 'Amr Ibn Shalah, Siyanah Shahih Muslim min alIkhlal wa al-Ghalat ( Beirut: Daar al-Ghaarb al-Islami, 1984), 45; Abu Bakar Ahmad bin Sahl al-Sarakhsi, Al-Muharrar fiy Ushul al-Figh (Beirut: Daar al-Kutb al-'Ilmiyah,1996), 269; Muhy al-Din An-Nawawi, Al-Taqrib wa al-Taysir li Ma'rifah Sunan al-Basyir wa al-Nadzir (Beirut: Dar al-Jinan, 1986), 21; and Sirajuddin al-Bulqani, Mahasin al-Istilah, published at Ibnu Shalah, Mukaddimah Ibn Shalah wa Mahasin alIstilah, 1989, 171-172. In Mun'im Sirry, Tradisi Intelektual Muslim;...,126-129.

${ }^{14}$ See: Ulrike Mitter, "The Majority Of The Dwellers Of HellFire Are Women" A Short Analysis of a Much Discussed Hadith. Dalam The Transmission and Dynamics of the Textual Sources of Islam; Essays in Honour of Harald Motzki, Edited: Nicolet Boekhoff-van der Voort, Kees Versteegh and Joas Wagemakers (Leiden: Koninklijke Brill NV, 2011), 462.

${ }^{15}$ The maudhui method is important because the hadith is a unified whole although the editors look different, the traditions interpret each other. The urgency of this method was expressed
} 


\section{The Number of Women in Hell}

Four versions of the emergence of this tradition about the majority of women who live in Hell are narrated in various books of hadith; begins with the suggestion of charity, begins with an eclipse explanation, starts with a description of the needy inhabiting paradise, and begins with the poor entering heaven first. ${ }^{16}$

a. Hadith about women are asked to give charity because they will be the majority of the inhabitants of hell; it is due to many women cursing and denying the kindness of the husband. The full version is narrated in the book of Sahih Bukhari hadith no. 1462:



by many scholars and scholars including Ahmad ibn Hanbal, Yusuf al-Qardhawi and Ali Mustafa Ya'qub. For more details, see: Al-Khatib al-Baghdadi, al-Jami 'li Akhlaq al-Rawi wa Adab al-Sima', Vol. 2 (Riyad: Maktabah al-Ma'arif, n.d.), 212; Yusuf al-Qardhawi, Kayf Nata'amal ma'a al-Sunnah al Nabawiyyah (Cairo: Dar al-Shuruq, 2002), 123; Ali Mustafa Ya'qub, alTurq al-Sahihah fi Fahm al-Sunnah al-Nabawiyyah (Ciputat: Maktabah Dar al-Sunnah, 2016), 118. Assessing hadith from two different sides (e.g. heaven-hell, poor-rich, male-female, etc.) also offered by Jasser Auda with a feature he called MultiDimensionality. See: Jasser Auda, Maqasid al-Shariah as Philosophy of Islamic Law; A Systems Approach (London: The International Institute of Islamic Thought, 2008), 224.

${ }^{16}$ The Mitter mapped it into three versions only, the traditions of the poor and poor are included in one section. For more details, see: Ulrike Mitter, "The Majority of The Dwellers of Hell-Fire Are Women ..., 444-446,

${ }^{17}$ This hadith is narrated in: Shahih Bukhari no.304, no.1462; Sahih Muslim, no.79; Sunan at-Tirmidzi no. 2613; Sunan Ibnu Majah no. 4003; Musnad Ahmad; no.3569, 4019, 4037, 4122, 5343, 8848, 26927; Sahih Ibnu Khuzaimah no.1000, 2461;
"Narrated Abu Said al-Khudri on 'Idul Fitr or 'Idul Adha Allah's Apostle (p.b.u.h) went out to the Musalla. After finishing the prayer, he delivered the sermon and ordered the people to give alms. He said, "O people! Give alms." Then he went towards the women and said. "O women! Give alms, for I have seen that the majority of the dwellers of Hell-Fire were you (women)." The women asked, "O Allah's Apostle! What is the reason for it?" He replied, "O women! You curse frequently, and are ungrateful to your husbands. I have not seen anyone more deficient in intelligence and religion than you. $O$ women, some of you can lead a cautious wise man astray." Then he left. And when he reached his house, Zainab, the wife of Ibn Mas'ud, came and asked permission to enter. It was said, "O Allah's Apostle! It is Zainab." He asked, 'Which Zainab?" The reply was that she was the wife of Ibn Mas'ub. He said, "Yes, allow her to enter." And she was admitted. Then she said, "O Prophet of Allah! Today you ordered people to give alms and I had an ornament and intended to give it as alms, but Ibn Mas'ud said that he and his children deserved it more than anybody

Sahih Ibnu Hibban no.5744. See: Abi Abdillah Muhammad Ibn Isma'il al-Bukhari (selanjutnya disebut al-Bukhari), Al-Jami'al$\underline{S} a \underline{h} \underline{i} \underline{h}$, Vol. 1 (Kairo: al-Mat'baah al-Salafiyah wamaktabatuha, 1400 H.), 114-115, 452; Al-Imam Abi al-Husain Muslim bin al-Hajjaj bin Muslim al-Qusyairy an-Naisabury (selanjutnya disebut Muslim), Sahih Muslim, Vol. 1 (Beirut: Daar al-Kutb al'Ilmiyah, 2008), 88; Al-Imam al-Hafiz Abiy 'Isya Muhammad Ibn 'Isya al-Tirmidzi (called al-Tirmidzi), Al-Jami' al-Kabir, Vol. 4 (Beirut: Daar al-Gharb al-Islamiy, 1996), 359-360; Abi Abdillah Muhammad Ibn Yazid al-Qazwiniy (called Ibnu Majah), Sunan Ibnu Majah (Riyadh: Maktabah al-Ma'rifah liNasya wa al-Tauzii', 1417 H ), 661; Ahmad bin Muhammad bin Hanbal (called Ahmad bin Hanbal), Al-Musnad (Cairo: Daar alHadis, 1995), Vol. 3: 490-491; Vol. 4: 118, 124, 150; Vol. 5: 26-27; Vol. 9: 27-28; Vol. 18: 406; Abi Bakr Muhammad Ibn Ishaq Ibn Khuzaimah an-Naisabury (called Ibn Khuzaimah), Shahih Ibn Khuzaimah (Riyadh: t.p, 1981), Vol. 2: 101; Vol. 4: 106-107; Al-Amir 'Alauddin 'aliy Ibn Balban al-Farisy (called Ibnu Balban), Shahih Ibnu Hibban bi Tartib Ibn Balban, Vol. 13 (Beirut: al-Resalah, 1997), 54-55. 
else." The Prophet replied, "Ibn Mas'ud had spoken the truth. Your husband and your children had more right to it than anybody else."

On that happy holiday, the Prophet advised Muslims not to mention women; all were encouraged to give alms. After completing his advice, the Prophet passed a group of women and encouraged them to give alms to avoid the fires of hell. This suggestion seems to be a repetition of the recommendations at the time the Prophet confronted the Muslims before. However, this hadith is often cited by not displaying the full version so that the word أَيَّهَا النَّاسُ، نَصَدَّقُُو the hadith's matan and is also a suggestion of the Prophet to all men and women no longer appear. That gives the impression that the Prophet (peace be upon him) advocating giving alms to avoid the fires of hell is exclusively for women.

Indeed, the hadith describes the words of the Prophet on three objects; first, to Muslim men and women, second, to women only, and third, to a Zainab. The Prophet advocated giving alms without exception, over time; the more detailed the Prophet's explanation on these objects. The causes of the majority of women going to hell are explanatory information so that women understand their vulnerable causes to go to hell. If at that time they listened to the advice of a group of men and then they questioned it again to the Prophet, then the Prophet might explain some of the causes that are vulnerable to making men as residents of hell.

The word should not be understood as a threat but as a warning because the Prophet did not want his people - including women - to be inhabitants of hell. Precisely the recommended sadaqah is not heavy; it can even be said in favor of women because a wife who gives away her wealth to her husband and children is supposed to get two benefits/ reward - the reward of relatives and alms. ${ }^{18}$ The kufr referred to in the hadith is not $k u f r$, that causes a wife to leave her religion. ${ }^{19}$

The discourse on understanding condemnation and denying the kindness of the husband as the cause of women going to hell is still problematic. For those who understand textually, it would be concluded that women do have this attitude. As Ahmad Fudhaili, said that the factor of busyness and routine affects someone in the curse, the busier and denser the habit the less chance to do things that are not useful. Women in the time of the Prophet were not yet preoccupied with public activities so they had more free time. He further stated that cursing did not only apply to women but also to men and with a lot of condemnation cannot be used as an excuse for them (men or women) to be tortured. As for the attitude of women who deny the goodness, the hadith was revealed during the role of men as givers and women as recipients, so women were not good at thanking the goodness of her husband or other kindness. At present the terms can be given as givers and husbands as recipients, so the husband must be grateful for the wife's gift. The goodness in question is not limited to the kindness between husband and wife but the meaning of hadith is all kindness. ${ }^{20}$

Moreover, This opinion needs to be reexamined because it removed some of the substance of the hadith message, because if it is said to be a lot of damnation it cannot be used as an excuse to bring torture, it could be

\footnotetext{
${ }^{18}$ See: Ahmad bin Hanbal, Al-Musnad, Vol. 18: 406.

${ }^{19}$ See: al-Asqalaniy, Fathul Bāri ..., Vol. 1: 83. The word of ma'syar means a group of people who have the same business, while al-'asyiir in the context of this hadith is the husband. See: al-Imam al-Hafiz Muhyiddin Abu Zakariyya bin Syaraf bin Murriy an-Nawawiy (here in after referred to as an-Nawawiy), Sahih Muslim bisyarh an-Nawawiy (t.tp: Mu'assisah alQurthubah, 1994), Vol. 2: 88; see also: al-Asqalaniy, Fathul Bāri ..., Vol. 9: 210.

${ }^{20}$ See: Ahmad Fudhaili, Perempuan di Lembaran Suci; Kritik atas Hadis-hadis Shahih (Jakarta: Kementerian Agama Republik Indonesia, 2012), 169-172.
} 
that cursing will easily and frequently occur in marital relations and it certainly has a negative impact on harmony and household continuity.

b. Hadiths about Eclipses; The Holy Prophet answered the companions' questions about his attitude reaching out and then stepping back. The Prophet explained that he had seen the heaven and the hell. In the Bukhari version no. 5197 it says:

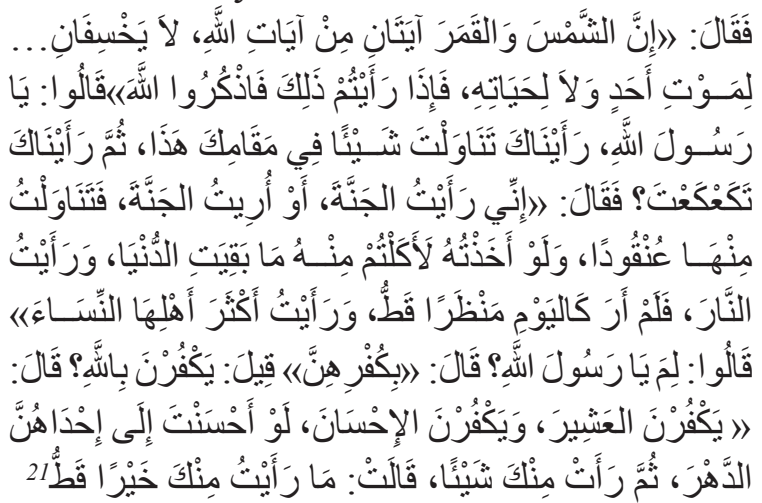

“... Rasulullah SAW said,” Verily the sun and moon are two signs between the signs of Allah's power, both of them did not experience an eclipse due to someone's death or birth. If you see that, then dhikr to Allah "They asked; "O Messenger of Allah! We see you reach something in this place, then we see you moving backward." He said, "I saw heaven or heaven was shown to me, I will also reach the bunch that is in heaven, if I take it, surely you will eat it while the world is still there. I saw hell - or it was shown hell to me, I have

\footnotetext{
${ }^{21}$ No less than seven lines of sanad who narrated this hadith from a friend, Abdillah ibn 'Abbas. Narrated in the Book of Saheeh Bukhari no.29, 1052, 5197; Sahih Muslim no.907; an-Nasa'iy no.1493; Musnad Ahmad no.2711,3374, al-Muwatta 'no.2, 186; Shahih Ibnu Khuzaimah no.1377. Although narrated in meaning, but there are only a few differences in the editorial of matan from each of the sanad lines. For more details, see: al-Bukhari, al-Jami 'al-Shahih, Vol. 1: 26,331-332; Vol. 3: 548; Muslim, Sahih Muslim, Vol. 3: 38-39; Jalaluddin al-Suyuthy (here in after referred to as al-Suyuthy), Sunan an-Nasa'i bi Syarh al-Hafiz Jalaluddin al-Suyuthy, Vol. 2 (Beirut: Daar al-Fikr, 2009), 145146; Ahmad bin Hanbal, al-Musnad, vol. 3: 211-212, 426-427; Imam Malik bin Anas, al-Muwatha' (Beirut: Dar al-Kitab alrArabiy, 2004), 82; Ibn Khuzaimah, Shahih Ibn Khuzaimah, Vol. 2: 312-313.
}

never seen such a scene today, and I see most of its inhabitants are women. "They asked," Why O Messenger of Allah! "He answered," Because of their kufr ", it was said," Are they Kufr to Allah? "He said," They are Kufr towards their husbands and Kufr towards goodness, "if you do good to one of them for a very long time, then they see something from you, surely he will say; "I've never seen your kindness at all."

It happened during kusuf (the solar eclipse praying). ${ }^{22}$ Al-Qadhi Iyadh said: Scholars have opinions that the Messenger of Allah was thought to have seen heaven and hell directly because Allah had removed the barrier to his senses of vision. Other opinions of the scholars perhaps also experienced by the Prophet Muhammad was only limited to revelation. But according to al-Qadhi, the first method of interpreting was better and closer to the editorial understanding. ${ }^{23}$

This hadith is long enough to begin an explanation that there had been a solar eclipse during the time of the Prophet, then he and people prayed. After praying, the sun had been revealed, the Messenger of Allah delivered his words about the sun and moon as signs of His greatness, it was at the time of the delivery of that word that the Companions witnessed the Messenger of Allah moving forward and then backward, when the Prophet was shown him heaven and hell.

c. The hadith is preceded by many needy people entering heaven. Narrated in several hadith books with a short version. In the Bukhari version it is mentioned:

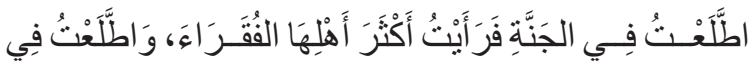



\footnotetext{
${ }^{22}$ See: al-Asqalaniy, Fathul Bāri..., Vol. 1: 405.

${ }^{23}$ See: an-Nawawiy, Sahih Muslim bi Syarh an-Nawawiy, Vol. 6: 294.

${ }^{24} \mathrm{No}$ less than thirteen sanad lines that narrated this hadith from
} 
"I once looked in heaven, apparently most of the inhabitants were poor people, and I also looked in hell, apparently most of the residents are women."

Al-faqr is a condition of not owning property or having few possessions. Ibn Bathal said, "The editor of the hadith suggested that the poor are more important than the rich, but the real meaning was the more poor people in the world than rich people. So it was not poverty that put them into heaven because of their shift even though they poor. ${ }^{25}$

d. The hadith about the poor first and more enter heaven than the rich (the word used المَنَسـاكِين not الفُقَرَاءَ), in Bukhari version mentioned:

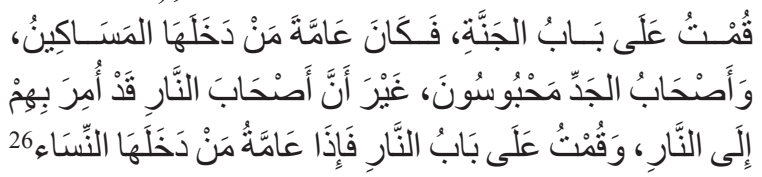

"I stood at the door of heaven, it turns out that most who enter it are poor people, while people who have wealth are restrained, except the experts of hell, then they have been ordered to go to hell, and I stand at the door of hell, apparently most of them enter it are women."

four friends namely 'Imran bin Husain, 'Abdillah Ibn Amrin, Ibn Abbas and Abu Hurairah. Narrated in the book of $\underline{S} a \underline{h} \underline{h} \underline{h}$ Bukhari no. 3241, 5198, 6449, 6546; Sahih Muslim no. 2737; Sunan atTirmidzi no.2602, 2603; Musnad Ahmad no. 3386, 6611, 7938, 19738, 19812, 19867. Sahih Ibnu Hibban no. 7455, 7489. For more details see: al-Bukhari, al-Jami 'al- $\underline{S} a \underline{h} \underline{h} \underline{h}$, Vol. 2: 367; Vol.

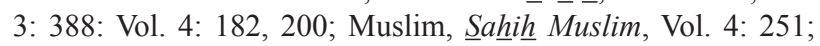
at-Tirmidzi, al-Jami 'al-Kabir, Vol. 4: 348; Ahmad bin Hanbal, al-Musnad, Vol. 3: 429; Vol. 6: 178-179; Vol. 8: 71; Vol. 15: 55,78,92; Ibn Balban, Sahih Ibnu Hibban bi Tartib Ibn Balban, Vol. 16: 493, 534-535.

${ }^{25}$ See: al-Asqalaniy, Fathul Bāri..., Vol. 11: 279-280.

${ }^{26}$ No less than nine sanad lines that narrate this hadith from a friend, Usamah Ibn Zaid Ibn Harithah. Narrated in the book of Sahih Bukhari no. 5196, 6547; Sahih $\underline{h}$ Muslim no.2736, Musnad Ahmad no.21782; $\underline{S}$ ahi $\underline{\text { I }}$ Ibnu Hibban no 692. For more detail

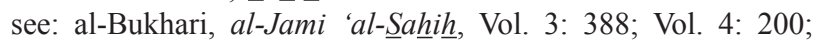
Muslim, Sahih Muslim, Vol. 4: 251; Ahmad bin Hanbal, alMusnad, Vol. 16: 94-95; Ibn Balban, $\underline{\text { S}} a \underline{\text { hih }}$ Ibn Hibban bi Tartib Ibn Balban, Vol. 2: 467.
These hadith used the word المَسنَسكِينُ is longer than the version of the hadith that uses the word الفُقَـرَاء, the two versions of the hadith also narrated by different friends, this الفُقََرَاءَ dan المَسَكَكِينُ although it has the same substance of the message, but the Prophet said at a different time.

In this hadith (المَنَساكِينُ), it was not only the indigent and women as the object of conversation but also the rich (أَصْحَـابُ الجَدِّ) ${ }^{27}$, this showed that the Prophet explained in two different locations - hell and heaven. In heaven, the Prophet compared the poor to the rich, that many poor people first entered heaven than the rich, without explaining what gender was more in heaven. As for the conditions in hell the Prophet only described the matter of more women entering hell without comparing with men. It seems that because the majority women go to hell, consequently minority men go to hell. Just as poor and rich are stated at the beginning of matan, so it is not true that because women are the majority in hell women become a minority in heaven. These two things are two different conditions.

According to Abu Syuqqah, the reason why rich people tend to be a little in heaven because they did more disobedience with their acts like taking illicit wealth, spending it on something unclean, stingy and did not want to donate it to good things. ${ }^{28}$

\section{The number of women in Heaven}

Although there are hadith stated,the number of women in hell was majority. But there are

\footnotetext{
27 According to one opinion, those who have good fortune in the world, those who are wealthy and domiciled, there are also those who think the meaning is rulers, they have been detained for five hundred years. See: Sharah Muslim, Vol. 17: 356. Rich people are restrained, they are prohibited from entering heaven with poor people because of property calculations. See: al-Asqalaniy, Fathul Bāri ..., Vol. 11: 420. ${ }^{28}$ See: Abdul Halim Abu Syuqqah, Kebebasan wanita, transalted by Chairul Halim, Vol. 1 (Depok: Gema Insani,2008), 271.
} 
hadith noted the number of women in heaven. Thus, there are two types of hadith appeared to be contradictory (mukhtalif), one mentioned the fewest women in heaven and the other suggested most in heaven. As Yusuf al-Qardhawi said wujub al-tatsabbut qabl al-hukm bi al-ta'arudl (it must verify before deciding the hadith is contradictory). ${ }^{29}$

a. The fewest inhabitants of heaven

In the Muslim version it is mentioned:

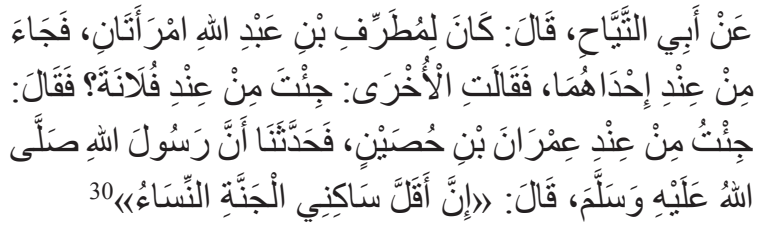

"From Abuat-Tayyah, he said, "Muthatrrif bin Abdullah had two wives, one time he came from one of his wives, then another wife asked him," Did you just come from Fulanah? "He replied," I came from Imran bin Hushain, he told us that the Messenger of Allah said; "Surely the minority of the inhabitants of heaven are women."

This Hadith is the only Hadith which is used as an argument that minority women are in heaven. Al-Asqalaniy argued that perhaps narrators narrate in terms of the meaning it understands, because women are the majority in hell, consequently their number is a minority in heaven. Yet this is not a necessity. Another possibility is that the hadith mentioned the beginning of entering Paradise before immoral women get out of hell because of syafa' $a$. $^{31}$

\footnotetext{
${ }^{29}$ Yusuf al-Qardhawi, Al-Marji'ayyah al-'Ulya fil Islam lil Qur'an wa al-Sunnah (Mesir: Maktabah, 2001), 200.

${ }^{30}$ No less than five paths that narrate this tradition from a friend, namely 'Imran bin Husain. Narrated in Sahih Muslim no.2738; Musnad Ahmad no.19837,19916,19986; Sahih Ibnu Hibban no.7457. in more detail, see: Muslim, $\underline{\text { S}} a \underline{h} \underline{i} \underline{h}$ Muslim, Vol. 4: 252; Ahmad bin Hanbal, al-Musnad, Vol. 15: 51-52,75,93; Ibn Balban, $\underline{S} a \underline{h} \underline{h}$ Ibn Hibban bi Tartib Ibn Balban, Vol. 16: 496.

${ }^{31}$ See: al-Asqalaniy, Fathul Bāri ..., Vol. 6: 325. Likewise ath-
}

After tracing the hadith narrated by Imran bin Hussein - the person from whom Muththarif listened to the hadith from other sanad, it was found that Imran bin Husain did not even mention that there were fewer women in heaven than men, possibly Muththarif was wrong in understanding the hadith Imran said or there was an intentional element. The full version of the hadith from Imran bin Husayn is:

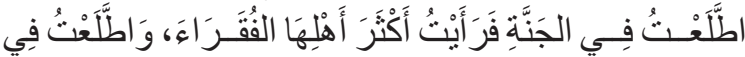

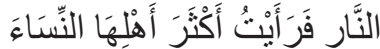

The Hadith did not compare the number of genders between women and men but between poor people and women. Muththarif seemed to draw his conclusions on the hadith narrated by Imran bin Husain in the form of consequences if the majority of women in hell then surely a minority woman in heaven. Muthatrif did not convey a complete version as sent by Imran, Muththarif could have concluded to overcome the jealousy of his wife, who questioned Muththarif's return from another wife's home. So, that the conclusion of the hadith was allegedly used by Muththarif as a form of "threat" to his wife so as not to make a longer issue about his existence at the home of another wife. Thus, al-Asqalaniy's opinion of the first possibility as mentioned earlier is more acceptable.

b. Most women in heaven

In the Muslim version it was mentioned:



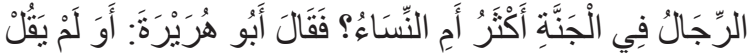

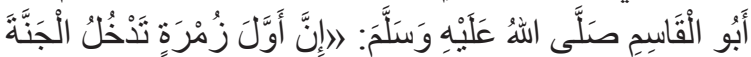

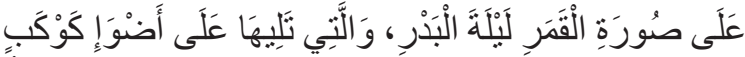

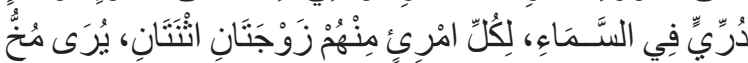

Thabakh argues that after women who are wicked get sharia, they enter heaven so that the majority of women in heaven See: Mahmud Fuad ath-Thabbakh, Mengapa Wanita berbuat Zhalim dan dizhalimi?, translator: Hamzah Taufik (Jakarta: Cendikia Sentra Muslim, 2004), 35 


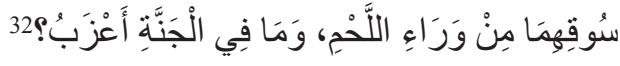

“... Having preached to us [Job] from [Muhammad] he said: Maybe they are boasting about one another or mentioning that there are more men or women in heaven? Then Abu Hurairah: Isn't Abu al-Qasim Saw said: "Surely the first group who enters heaven is like the moon at full moon, the next group looks like the brightest star in the sky and every man between them has two wives, both calf bones visible from both flesh and heaven there is no single person."

Al-Asqalaniy argued that the two wives in question are from women in the world. In zahir that every man in heaven has at least two wives. At the time of friends, people consisting of men and women arguing with each other boast of their gender as the most inhabitants of heaven. So Abu Hurairah reminded them of a Prophet's hadith, which states that every man in heaven has a partner and the partners of each man are two women. That means that there are more women than men in paradise.

\section{Discourse on Typology of Understanding The Hadith}

Scholars have different in understanding the hadith about the number of women as occupants of heaven and hell. The paradigm is generally divided into three types of understanding of the typology of hadith-normative-textual paradigm (al-dalâlah al-ashliyah), historical-contextual paradigm and rejectionist-liberal paradigm. ${ }^{33}$

\footnotetext{
${ }^{32}$ No less than thirteen sanad lines that narrate this hadith from two best friends namely Abu Hurairah and Abu Said al-Khudri. Narrated in the book of $\underline{S}$ ahi $\underline{h}$ Bukhari no.3245,3246, 3254,3327; Sahih Muslim no.2834; Sunan at-Tirmidzi no. 2522, 2535, 2537.

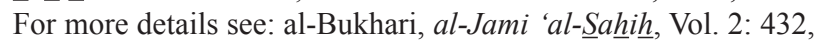
433,434,450; Muslim, $\underline{S}$ a $\underline{h} \underline{i} \underline{h}$ Muslim, Vol. 4: 312; at-Tirmidzi, al-Jami 'al-Kabir, Vol. 4: 288-289, 299,300.

${ }^{33}$ The typology of the understanding of this hadith paradigm is traced to the historical approach (historical approach), in more detail see: Abdul Mustaqim, Science Ma'anil Hadith ..., 28-32
}

The normative-textual paradigm understands that the text of the hadith must be understood as is according to the sound of the text. In this case, women are understood as being with the most sexes occupying hell and as a consequence the fewest women are in heaven. This understanding is usually accompanied by an explanation that women do have properties that are no better than men, as the opinion of al-Qurthubi, he stated:

"Indeed, few women enter heaven because they are defeated by lust and are more inclined to the glitter of the world, due to their lack of mind to pay attention to the afterlife. They are unable to practice the afterlife and inclination to the world and decorate themselves for them. They are the main cause of turning away men from the afterlife because of lust and tendency towards women. Most women turn away from the afterlife because they themselves are easily fooled by the persuasion of those who turn away from religion and find it difficult to accept those who fear that the afterlife and its practices. "34

The historical-contextual paradigm did a thorough study of the hadith so that it did not rush to reject the hadith especially if the hadith was agreed by the majority of Sunni scholars as the authentic hadith, and used methodological stages; conducted historical studies by critically examining sanad and matan, conducting linguistic and hermeneutical studies by interconnecting with other disciplines. In this case, the hadith is still accepted but women were not necessarily accused of being beings who behave more badly than men. Women indeed the majority of the inhabitants of hell were due to the number being indeed more in the world than men, but not necessarily fewer women in heaven, among those who argue like Ibn Hajar al-Asqalaniy and an important figure of traditional Sunni eschatology in the century eighteen namely al-Saffarini. ${ }^{35}$ In terms of

\footnotetext{
${ }^{34}$ See: Muhammad bin Ahmad bin Farj al-Anshari al-Qurthubi, "Al-Tadzkirah Fiy Ahwali al-Mautiy wa Umur al-Akhirat," in Mahir Ahmad Ash-Shufiy, Neraka, Kengerian dan Siksaannya, translated by Badruddin, et.al. (Solo: Tiga Serangkai, 2007), 234. See: al-Asqalaniy, Fathul Bāri..., Vol 11: 420.

${ }^{35}$ See Muhammad al-Saffarini, The Swelling Oceans of Eschatology ( al-Buhur al-Zakhira fi ulum al-akhira), dalam
} 
commenting on the large number of women at the end of the an-Nawawi era and Abu Abdul Malik stated that it was due to many wars so many men were killed, but according to al-Asqalaniy this opinion needs to be reexamined because this was a phenomenon not caused for other reasons, but indeed God's destiny established at the end of time by reducing the number of sons born and multiplying daughters. ${ }^{36}$

Finally, the liberal rejectionist paradigm tends to reject the hadith which contradicts the mind even though the hadith is authentic. Like the paradigm of Abdul Hamid and Ashghar Ali Engineer quoted by Zaitunah Subhan, ${ }^{37}$ Hidayet Sefkatli Tuksal and Mohammad Ali Syed. According to Ali Syed, there are eight hadith related to women that have been denied authenticity, including the traditions of the majority of the inhabitants of hell are women. He argued that history recorded the attention and proper treatment of the Prophet was very large for women. Impossible for the Prophet to say this is outrageous. It is necessary if the hadith is rejected, even though it is collected in authentic books such as authentic Bukhari. Ali Syed also argued that the hadith explained that the majority of the inhabitants of heaven are the poor and the majority of the inhabitants of hell are women is an authentic hadith from the Prophet, may not come from the Prophet, because how could the Prophet be able to count every inhabitant of heaven and hell based on their gender and wealth. Thus, this statement cannot be accepted as an authentic hadith because of the contradiction with the spirit and encouragement of the Qur'an, Ali Syed argues. ${ }^{38}$

Christian Lange, Paradise and Hell in Islamic Traditions (New York: Cambridge University Press, 2016), 89-90

${ }^{36}$ Al-Asqalaniy, Fathul Bāri..., Vol. 1: 179. See: An-Nawawiy, Sahih $\underline{h}$ Muslim Bisyarh an-Nawawiy, Vol. 7: 135.

${ }^{37}$ According to Abdul Hamid dan Asghar Ali, Hadith is unacceptable because it does not make sense and is not in line with the Qur'an. Furthermore Zaitunah argues that the hadith cannot be taken for granted its literal meaning, even though it is contained in the authentic book which has been recognized by Sunni scholars. See: Zaitunah Subhan, Tafsir Kebencian; Studi bias Gender dalam Tafsir Qur'an (Yogyakarta: LKiS Yogyakarta, 1999), 63-43.

${ }^{38}$ Mohammad Ali Syed., 22.
Moreover, Ulrike Mitter conducted an isnad cum matn analysis and concluded that the hadith about hell with its various versions was not from the Prophet, ${ }^{39}$ he believed that something must have happened during the time of friends, something many people hear without knowing the details, and Muslim men at that time felt happy with the existence of such hadiths so that it connected with other traditions such as alms, solar eclipses; and expand the issue of ingratitude and lack of women. Mitter also expressed his astonishment that there was not a single woman as the narrator of the hadith, even though the Prophet discussed it directly with women..$^{40}$ In This case seems that Mitter has not yet found the path of a female friend's sanad on the alms version of the hadith narrated in the book of Ahmad bin Hanbal, in the order: Rasulullah $\mathrm{Saw} \rightarrow$ Zainab $\rightarrow$ anak saudara Zainab $\rightarrow$ Amri dan Ibn Haritz Ibn Musthaliq $\rightarrow$ Syaqiq $\rightarrow$ alA'masy $\rightarrow$ Abu Mu'awiyyah. ${ }^{41}$

\section{Method of Calculating The ProbabiLlity of Hadith}

Calculate the ratio probability ${ }^{42}$ women and men in heaven and hell are necessary on a

\footnotetext{
${ }^{39} \mathrm{Or}$ it can be said maudhu' (fake), an example of Mitter's analysis is that in the hadith version of the eclipse of Zaid bin Aslam is the commond link (main link) but he is also one of the people who narrated the alms version of hadith, so that there is a possibility of Zaid mixing the alms hadith matan with matan about prayer during an eclipse. Therefore Mitter considered the eclipse hadith as alms had also existed at the beginning of the second century. In my opinion, this analysis needs to be reviewed because it is not impossible for a person - in this case the Prophet - to express a similar problem in different situations or conditions. He could have revealed the majority of women who inhabit hell at different times (for example; on the feast of Eid al-Fitr/Eid al-Adha and on the eclipse prayer sermon), so, it is not an attempt to merge the two different traditions by the narrator (Zaid bin) Aslam). Besides that, the i'Atibar sanad by Mitter also seems incomplete. See: Ulrike Mitter, The Majority of The Dwellers of Hell-Fire Are Women ..., 445.

${ }^{40}$ See: Ulrike Mitter, The Majority Of The Dwellers Of Hell-Fire Are Women ..., 461.

${ }^{41}$ See:Ahmad bin Hanbal, Al-Musnad, Vol. 18: 406.

${ }^{42}$ Ratio is a comparison between two things that are interconnected, usually displayed in the form of numbers. As in this paper the ratio referred to is the ratio between the number of men and women in their capacity as occupants of heaven or hell, not comparing the quantity between the inhabitants of heaven and hell.
} 
counting scale, but there was no data on the exact population of the two genders in this world or the hereafter. However, there was hadith informed the ratio at the end of time, this hadith was then used as a calculation scale in this paper. The two hadiths mentioned are:

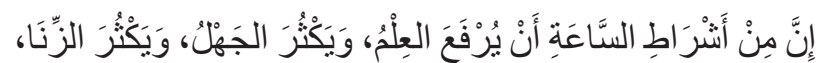

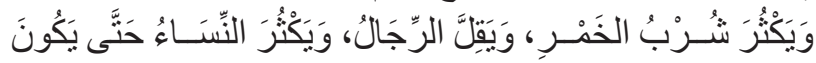

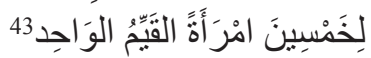

"Surely among the signs of doomsday is ... more women and fewer men, to the point that (the comparison) is fifty women equal to only one man."

Others:



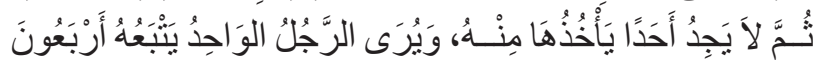

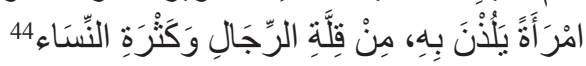

"And a man will be followed by forty women, whom they want to have fun with."

The number of women and men was 50 compared to 1 or 50: 1 and 40 compared to 1 or 40 : 1 , according to al-Asqalaniy, the word may also be a figure of speech describing a large number of women. ${ }^{45}$ Although these two types of ratios can be used as a calculation scale, in this paper the range used is only 50: 1 because the calculation with the two types of ratios ultimately results in a substance that is no different, namely the ratio of women far more than men. ${ }^{46}$

${ }^{43}$ It's in the book $\underline{S}$ ahih al-Bukhari, no.81, no.5231, no.5577, no.6808; Sahih Muslim, no. 2671, Sunan Ibnu Majah, no. 4045; Sunan at-Tirmidzi, no. 2205. For detail see: al-Bukhari, Al-Jami'

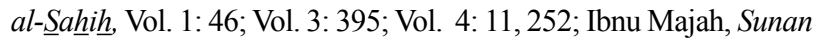
Ibnu Majah, 667-668; at-Tirmidzi, Al-Jami'al-Kabir, Vol. 4: 67-68. ${ }^{44}$ Narrated in the Book $\underline{S} a \underline{h} \underline{i} \underline{h}$ Bukhari, no. 1414; Shahih Muslim

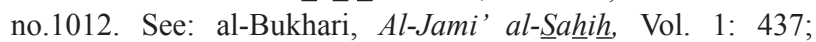
Muslim, $\underline{\text { Sahih }} \underline{\underline{h}}$ Muslim, Vol. 2: 92.

${ }^{45}$ Al-Asqalaniy, Fathul Bāri..., Vol. 1: 179.

${ }^{46}$ Badriyah Fayuni and Alai Najib had also previously sought to explore the meaning of the majority of women as inhabitants of hell as stated in the hadith, and to relate it to the hadith about the ratio of men and women at the end of time, namely $1: 50$. So according to them, the majority of women in hell is due to the quantity of women who are indeed more. Some of
The number 1 in the 1:50 hadith ratio was the smallest number that could be paired for a human; it means each human consists of 1 or alone. The human self could not be lower than 1 (not fractions but integers). To be able to distribute the numbers, the ratio must be increased by each digit multiplied by the same amount, for example by the number 20 , so $1 \times 20=20$, and $50 \times 20=$ 1000 so that the ratio 1:50 $=20: 1000$. It made it easy to divide and according to the probability distribution function it cannot be negative.

Men and women, in this case,were variables that have characteristics and can be observed. In this paper, discrete random variables were used to retrieve absolute separate values, resulting from the calculation of an object. For example, if 100 employees, then counting people who did not come to work on Monday took amounts $0,1,2,3, \ldots 100,{ }^{47}$ the authors interpret that: for example, if the number of women in the world was 100 then the counting of women who go to hell can take values of $0,1,2,3, \ldots 100$. Likewise, the calculation of women who entered heaven took the values $0,1,2,3, \ldots 100$; so that every woman had the same opportunity to enter hell or heaven. This statistic described a relationship or association between several variables, namely Women (P), Men (L), Heaven (S) and Hell $(\mathrm{N})$. Regarding these interconnected variables explained that:Variables are called related if the relationship in such wayby knowing the state of one variable, it supposed the other variables." 48

In short, examining the hadith quantity

the methodologies they use in part do have similarities with this paper, namely in terms of using the hadith ratio in reasoning the majority of women in hell, but this paper seeks to explain in more detail with the display of numbers through the method of probability logic. See: Badriyah Fayuni and Alai Najib, "Makhluk yang Paling Mendapat Perhatian Nabi: Perempuan Dalam Hadis," in Ali Muhanif, Mutiara Terpendam; Perempuan dalam Literatur Islam Klasik (Jakarta: Gramedia Pustaka Utama, 2002), 59.

${ }^{47}$ Another type of variable is a continuous random variable that is used to measure something like the width of a room and so on, and it is not suitable for this study. See: J. Supranto, Statistics ..., 2-5. ${ }^{48}$ Riduwan and Akdon, Rumus dan Data dalam Aplikasi Statistika; untuk penelitian Administrasi Pendidikan-BisnisPemerintahan-sosial-kebijakan-Ekonomi-Hukum-ManajemenKesehatan, Ed. 4 (Bandung: Alfabeta, 2010), 9 
of women in hell and heaven revealed the opportunity to find information about the number of men. It is essential because there are no verses or traditions that explicitly mention the quantity of men both in heaven and in hell.

\section{The Gender Ratio of The Inhabitants of Heaven and Hell}

Several possible assumptions to test the value of the ratio of probabilities in terms of the quantity of gender of the inhabitants of heaven and hell: (1) Men; > in hell, < in heaven. (2) Men; > in hell, $=$ the number of women in heaven. (3) Men; $>$ in hell, > in heaven, (4) Men; > in heaven, < in hell. (4) Men; > in heaven, = the number of women in hell. (5) Men; < in hell, = the number of women in heaven. (6) Men; < in hell, < in heaven. (7). Men; $<$ in heaven, $=$ the number of women in hell.

From these assumptions, it could be analyzed that if heaven made as a starting point, then there were only three possible ratios, (1). Women were more heavenly than men (2).Women and men alike in heaven (3). Fewer women in heaven than men. These three assumptions would be tested so that later they will also produce answers to other premises. Therefore, then, in the search for a probability calculation focused on the ratio in heaven by placing the smallest number 1 on each assumption, as the lowest number of an individual human being. Rates of 1: 50 were for the first assumption, 1: 1 was for the second assumption and 2: 1 was for the third assumption.

Table 1. Assumptions for male and female probability ratios-as a resident of heaven-hell on a scale of 20: 1000

\begin{tabular}{cccccc}
\hline Probability & \multicolumn{2}{c}{ Heaven (S) } & \multicolumn{2}{c}{ Hell (N) } & \multirow{2}{*}{ Formulation } \\
\cline { 2 - 5 } & Men (M) & Women (W) & Men (M) & Women (W) & S and N=(W>M) \\
\hline I & 1 & 50 & 19 & 950 & \\
\hline II & 1 & 1 & 19 & 999 & $\begin{array}{l}\mathrm{S}=(\mathrm{W}=\mathrm{M}) \\
\mathrm{N}=(\mathrm{W}>\mathrm{M})\end{array}$ \\
\hline III & 2 & 1 & 18 & 999 & $\begin{array}{l}\mathrm{S}=(\mathrm{W}<\mathrm{M}) \\
\mathrm{N}=(\mathrm{W}>\mathrm{M})\end{array}$ \\
\hline
\end{tabular}

Table 2. Probability values of men and women-as residents of heaven-hell

Formula:

The probability of an event occurring $=\underline{\text { Number/Frequency of Occurrence }}$ Number of observations

\begin{tabular}{lll}
\multicolumn{1}{c}{ Probability I } & \multicolumn{1}{c}{ Probability II } & \multicolumn{1}{c}{ Probability III } \\
\hline$\frac{1}{20}=0,05 \mathrm{M}$ in heaven & $\frac{1}{20}=0,05 \mathrm{M}$ in heaven & $\frac{2}{20}=0,1 \mathrm{M}$ in heaven \\
\hline$\frac{50}{1000}=0,05 \mathrm{~W}$ in heaven & $\frac{1}{1000}=0,001 \mathrm{~W}$ in heaven & $\frac{1}{\frac{1}{1000}}=0,001 \mathrm{~W}$ in heaven \\
$\frac{\frac{19}{20}=0,95 \mathrm{M} \text { in hell }}{\frac{19}{20}=0,9 \mathrm{M} \text { in hell }}$ \\
$\frac{\frac{19}{20}}{1000}=0,95 \mathrm{~W}$ in hell & $\frac{999}{1000}=0,95 \mathrm{M}$ in hell & $\frac{999}{1000}=0,999 \mathrm{~W}$ in hell \\
\hline
\end{tabular}

on a scale of 20: 1000 in the form of decimal fractions

In table 1 , the first probability pointed out that men were minority inhabitants in hell but at the same time a minority in heaven. On the contrary, women indicated that the number was indeed the majority in hell, but at the same time, the majority in heaven. The distribution 
used balanced percentage multiplications, each multiplied by $5 \%$; that is, $20 \times 5 \%=1,1000 \times 5 \%$ $=50$. It was possible to use a greater percentage of $10 \%$, so that the ratio in heaven $=2: 100$ and in hell $=18: 900$, it means it still has the same conclusion. On this occasion it appeared that the number of men in heaven was far less than women, compared to 1:50, of the fifty women only one man. But of course this number was not certain, the comparison may not be too obvious, considering the count of 1:50 is the condition of the end times and not the conditions in the earlymiddle ages. In this possibility, the chances of each gender entering heaven were equal (5\%). It is accordance with the principles of the Qur'an. That both men and women have equal opportunities to enter heaven. ${ }^{49}$

The second probability identified that men were minority dwellers in hell and vice versa majority women, but the number of both genderequal in heaven. The division used unbalanced percentage multiplication, it because adjusts to the number of balanced ratios in heaven (i.e. 1: 1), it got the result of multiplying the percentage for men multiplied by $5 \%$ and for women multiplied by $0.1 \%(20 \times 5 \%=1$ and $1000 \times 0,1=1)$. It could be using a greater percentage of $10 \%$ and $0.2 \%$, so the ratio in heaven $=2: 2$ and in hell $=18: 998$. It means it still had the same conclusion. The number of male inhabitants of heaven was equal to women, but men had a far greater chance of entering heaven than women (in the table above, men have a $5 \%$ chance of entering heaven, while women have $0.1 \%$ ). This is contrary to the principle of the Qur'an. Then this probability was difficult or even impossible.

The third probability displayed that men were minority dwellers in hell and majority women. In heaven, on the other hand, the majority of

\footnotetext{
${ }^{49}$ See: Q.S. 4: 124 ("Whoever works on righteous deeds, both men and women, and those who believe, they enter into heaven ...”). Hadith/ sunnah must submit to the Qur'an, at least that is the opinion of some modern scholars such as Muhammad Abduh, Sayyid Ahmad Khan and William Mu'ir, See: Mun'im Sirry, Tradisi Intelektual Islam ...,81-82 .
}

men were heaven dwellers while the minority women. The division used unbalanced percentage multiplication, this was because it adjusts to the higher male ratio in heaven (i.e. $2: 1$ ), then the results were obtained for the percentage of multiplication for men multiplied by $10 \%$ and for women increased by $0.1 \%(20 \times 10 \%=2$ and $1000 \times 0,1=1)$. It could be using a greater percentage of $20 \%$ and $0.4 \%$ so that the ratio in heaven $=4: 2$ and in hell $=16: 998$. It means it still had the same conclusion. The number of men in heaven was higher than women with a very close ratio (2: 1), but it was precisely in the third chance that the percentage going to heaven was more significant for men than for women $(10 \%$ for men, $0.1 \%$ for women). So this was far from the principle of the Qur'an because of the more comprehensive the percentage of opportunities to enter paradise the distance for both.

Therefore, the first probability was appropriate to be used in understanding the meaning of the majority in the hadith about the inhabitants of hell, because it does not conflict with the principles of the Qur'an and is in line with the meaning of other related traditions. Besides, in terms of probability theory, the first probability was the most likely to occur because the lowest probability value is $5 \%$ or 0.05 , whereas the second and third chances were the lowest probability value of $1 \%$ or 0.001 (see table 2).

The table depicted the various opportunities emerge, the number of women living in hell was higher than men, none described the number of majority men in hell compared to women, if it was calculated based on the number in its population, the number of men The more men in the hell than in the heaven. It can be understood that the number of women in hell compared to men was due to the number of women who were indeed more than men. The ratio of smaller amounts was placed in the position of heaven and a more significant quantity was placed in the area of hell due to other hadith information, which states the number of inhabitants of hell more than the 
number of inhabitants of heaven..$^{50}$

\section{Conclusion}

Scientific integration gave opportunities to understand the meaning of hadith text more broadly; the statistical logic of probability was proven to be a method of understanding hadith. Although it does not ultimately provide the final certainty, at least as a frame of the possibility of what will happen. The hadith about the majority of women who live in Hell seems simple, but this issue has succeeded in creating a separate debate space among scholars, textual and contextual understanding of hadith reflected the debate discourse, even to the problem of accepting or rejecting the authenticity of the hadith even though it is contained in the canonical hadith books.

The results of the application of the probability method appeared the misogyny assumption of the text of hadith (matan hadith) that occurs because the interpreting party has lost some of its contexts. The Prophet stated that the majority of women who live in hell are in the context of the female population if it is compared. If the male population is the object of discussion then the number of males becomes the majority in hell than in heaven. So that the Prophet's utterance in this hadith is not something that discredits women, as is widely understood. Besides, the assumption that most women in hell are due to the inherent bad nature of women, as a result of comparing with man and releasing it from the context of the woman population, this is vulnerable to eliciting gender biased arguments, as if women were more 'not better 'than men, this condition is also

${ }^{50}$ Out of every 1000 people, there are 999 people who live in hell. (......), Narrated in the Book $\underline{S} a \underline{h} i \underline{h}$ Bukhari no. $6530, \underline{S} a \underline{h} \underline{h} \underline{h}$ Muslim no.222, See: al-Bukhari, Al-

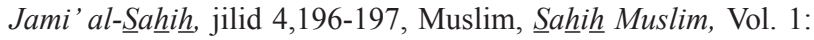
169-170. Similar opinion that the majority of earth's inhabitants are prospective inhabitants of hell, see: Zakaria Ouzon, Jinayat al-Bukhari; Inqadz al-Din min Imam al-Muhadditsin, (Beirut: Riad El-Rayyes Book, 2004), 122, in Muhammad Rikza Muqtada, "Kritik Nalar Hadis Misoginis," Jurnal Musawa 13. no. 2 (2014): 93. because the interpreting party has lost some of the hadith contexts.

This hadith isshahih in ishad and matan, needs to reconstruct the understanding of matan hadith. So that hadith listed in this canonical hadith book do not necessarily collapse. Besides, by acknowledging and accepting it does not mean releasing from the context of the population of gender, this causes gender injustice, men will behave arbitrarily to women, especially husbands to his wife by 'threatening' as majority occupants in hell who must follow her husband's orders even in terms of disobedience.

Thus, the logic of probability has at least contributed to providing a new perspective on the understanding of hadith (ma'anil hadith), especially in the hadith about the majority of women who inhabit hell from previously understood to biased until it is rejected into an understanding that is 'friendly' and gender just.

\section{References}

Akdon dan Riduwan. Rumus dan Data dalam Aplikasi Statistika; untuk penelitian Administrasi Pendidikan-Bisnis-Pemerintahan-sosialkebijakan-Ekonomi-Hukum-ManajemenKesehatan. Bandung: Alfabeta, 2010.

al-Asqalaniy, Ahmad bin Aliy bin Hajar, Fathul Baari bi Syarh shahih al-Bukhariy. Beirut: Daar al-Ma'rifah, n.d.

Auda, Jasser Maqasid al-Shariah as Philosophy of Islamic Law; A Systems Approach. London: The International Institute of Islamic Thought, 2008.

Aydemir, Halis. Probability of Narration; a Theoretical Approach. USA: LuLu Press, 2007.

al-Baghdadi, al-Khatib. al-Jami' li Akhlaq alRawi wa Adab al-Sima'. Vol. 2. Riyad: Maktabah al-Ma'arif, n.d. 
al-Bukhari, Abi Abdillah Muhammad Ibn Isma'il. Al-Jami' al-Sahih. Kairo: al-Mat'baah alSalafiyah wa Maktabatuha, $1400 \mathrm{H}$.

al-Farisy, al-Amir 'Alauddin 'aliy Ibn Balban. Sahih Ibnu Hibban bi Tartib Ibn Balban. Beirut: al-Resalah, 1997.

Fayuni, Badriyah dan Alai Najib. "Makhluk yang Paling Mendapat Perhatian Nabi: Perempuan Dalam Hadis.” In Ali Muhanif. Mutiara Terpendam; Perempuan dalam Literatur Islam Klasik. Jakarta: P.T Gramedia Pustaka Utama, 2002.

Fudhaili, Ahmad. Perempuan di Lembaran Suci; Kritik atas hadis-hadis Shahih. Jakarta: Kementerian Agama Republik Indonesia, 2012.

Husain, Rahmin Talib. "Wanita dalam Belenggu Neraka (Kritik Hadith Misoginis)". Jurnal UNIVERSUM: Jurnal Keislaman dan Kebudayaan 11. no. 2 (2017).

Ibn Anas, Imam Malik. Al-Muwatha'. Beirut: Dar al-Kitab al-'Arabiy, 2004.

Ibn Hanbal, Ahmad bin Muhammad. Al-Musnad. Kairo: Daar al-Hadis, 1995.

Ibn Khuzaimah, Abi Bakr Muhammad Ibn Ishaq. Sahih Ibn Khuzaimah. Riyadh: t.np, 1981.

Mitter, Ulrike. "The Majority of The Dwellers of Hell-Fire Are Women" A Short Analysis of a Much Discussed Hadith.” In Nicolet Boekhoff-van der Voort, Kees Versteegh and Joas Wagemakers (Ed.). The Transmission and Dynamics of the Textual Sources of Islam; Essays in Honour of Harald Motzki. Leiden: Koninklijke Brill NV, 2011.

Muqtada, Muhammad Rikza. "Kritik Nalar Hadis Misoginis". Jurnal Musawa 13. no. 2 (2014).

Mustaqim, Abdul. Ilmu Ma'anil Hadis; Paradigma Interkoneksi Berbagai Metode dan Pendekatan dalam Memahami Hadis Nabi. Yogyakarta: Idea Press, 2016.

an-Naisabury, al-Imam Abi al-Husain Muslim bin al-Hajjaj bin Muslim al-Qusyairy. Sahih Muslim. Beirut: Daar al-Kutb al-'Ilmiyah, 2008.

Nation, United. The World's Women 2000; Trends and Statistic. New York: United Nations Publications, 2000.

an-Nawawiy, al-Imam al-Hafiz Muhyiddin Abu Zakariyya bin Syaraf bin Murriy. Sahih Muslim bisyarh an-Nawawiy. t.tp: Mu'assisah al-Qurthubah, 1994.

al-Qardhawi, Yusuf. Kayf Nata'amal ma'a al-Sunnah al Nabawiyyah. Kairo: Dar alShuruq, 2002.

------. Al-Marji'ayyah al-'Ulya fil Islam lil Qur'an wa al-Sunnah. Mesir: Maktabah, 2001.

al-Qazwiniy, Abi Abdillah Muhammad Ibn Yazid. Sunan Ibnu Majah. Riyadh: Maktabah alMa'rifah li-Nasya wa al-Tauzii', 1417 H.

Qudratullah, et.al. Metode Statistika. Yogyakarta: Bidang Akademik UIN Sunan Kalijaga, 2008.

ash-Shufiy, Mahir Ahmad. Neraka, Kengerian dan Siksaannya. Translated by Badruddin et.al., Solo: Penerbit Tiga Serangkai, 2007.

Sirry, Mun'im. Tradisi Intelektual Muslim; Rekonfigurasi Sumber Otoritas Agama. Malang: Madani, 2015.

Soedibjo, B.S., "Statistika.” In Imam Gunawan. Pengantar Statistika Inferensial. Jakarta: Raja Grafindo Persada, 2016.

Supranto, J. Statistik Teori dan Aplikasi. Jakarta: Erlangga, 2001.

Susanti, Meilia Nur Indah. Statistika Deskriptif dan Induktif. Yogyakarta: Graha Ilmu, 2010. 
al-Suyuthy, Jalaluddin. Sunan an-Nasa'i bi Syarh al-Hafiz Jalaluddin al-Suyuthy. Beirut: Daar al-Fikr, 2009.

al-Saffarini, Muhammad. The Swelling Oceans of Eschatology (al-Buhur al-Zakhira fi ulum al-akhira). In Christian Lange. Paradise and Hell in Islamic Traditions. New York: Cambridge University Press, 2016.

Subhan, Zaitunah. Tafsir Kebencian; Studi Bias Gender dalam Tafsir Qur'an. Yogyakarta: LKiS Yogyakarta, 1999.

Syed, Mohammad Ali. The Position of Women in Islam: a Progressive view. New York: State University of New York, 2004.

Syuqqah, Abdul Halim Abu. Kebebasan Wanita. Translated by Chairul Halim. Depok: Gema Insani, 2008.

ath-Thabbakh, Mahmud Fuad. Mengapa Wanita
Berbuat Zhalim dan dizhalimi? Translated by Hamzah Taufik. Jakarta: Cendikia Sentra Muslim, 2004.

al-Tirmidzi, al-Imam al-Hafiz Abiy 'Isya Muhammad Ibn 'Isya. Al-Jami' al-Kabir. Beirut: Daar al-Gharb al-Islamiy, 1996.

Tuksal, Hidayet Sefkatli. "Misogynistic Reports in the Hadith Literature. In Ednan Aslan, Marcia Hermansen and Elif Medeni (ed.). Muslima Theology; The Voices of Muslim Women Theologians. Frankfurt Am Main: Peter Lang, 2013.

Ya'qub, Ali Mustafa. al-Turq al-Sahihah $f i$ Fahm al-Sunnah al-Nabawiyyah. Ciputat: Maktabah Dar al-Sunnah, 2016.

https://openlibrary.org/authors/OL6884914A/ Assoc._Prof._Dr._Halis_Aydemir. Accessed September 25, 2019. 